\section{Public Higher Education and Tuition: The Russian Case}

\section{Olga Bain}

Olga Bain is at the Center for Global and Comparative Education, State University of New York at Buffalo, 468 Baldy Hall, SUNY at Buffalo, Buffalo, NY 14260, USA. E-mail: <bain@acsu.buffalo.edu>.

$\mathrm{I}^{\mathrm{n}}$ n today's Russia, tuition plays an important role in the economics of public higher education. Many public institutions have become dependent on tuition revenues as the second major source of income after state allocations. Some view tuition as a potential mechanism, when coupled with means-tested financial aid, for rendering higher education more equitably accessible an the increasingly incomedifferentiated Russian society. Tuition policy remains, however, a highly sensitive public issue that adds to the already significant social costs brought about by the postperestroika reforms and reduction in the public safety net.

The new private (nonstate) sector of higher education presently accounts for 6.9 percent of the nation's tuitionbased enrollments. The overwhelming majority of students who pay for their studies are enrolled in public universities and colleges, where 84 percent of students are not yet charged tuition. Students who do pay tuition were either admitted for a second degree or had scores that fell just below the cutoff point for passing the entrance exams. Tuition payments are provided either from individual resources or by sponsoring prospective employers.

After a 1993 drop in enrollments in the public sector, admissions to state higher education institutions rose by one-fifth in five years. Close to three-fifths of this growth was accounted for by the increase in admissions with tuition charges in state higher education institutions. Over this period not only the absolute numbers but also the rates of increase in admissions with tuition were higher in state institutions than in nonstate ones.

Instruction on a fee-paying basis is geared to the market value of a program and the prestige of the institution rather than to the actually incurred costs. Since the most demand-driven programs-such as those in law, economics, management, and foreign languages-are relatively inexpensive to provide, the tuition revenue is used to subsidize costlier programs and general university operations.

Because of fluctuating inflation, instruction is priced on a semester-to-semester basis, making financial planning more difficult for students and parents. Some prestigious institutions require an up-front fee for the first three years of instruction. Others have developed more flexible schemes, offering students several options of tuition payment. Yet another smaller group of institutions has introduced prepaid tuition schemes, in which payment is collected over a short period of several months before admission.
Affordability of higher education programs is primarily a function of individual incomes and savings, which are difficult to estimate in today's Russia. According to official statistics, real disposable incomes have continued to decline in the past two years; 22.5 percent of the population fell below the poverty line; and the incomes of the richest 10 percent of the population were 13.2 times greater than the incomes of the poorest 10 percent. At the same time, experts estimate underreporting of incomes by 40 percent in the nonstate sector, mainly in reaction to the pressure of abusively high tax rates. The total recorded savings rates are low, and the amount of cash kept outside banks can only be estimated.

The evidence of an increasingly stratified society calls into question the very existence of a stable and healthy middle class in Russia today. Some 37.5 percent of the employed population have jobs in the public sector, where salary arrears have continued to accrue over the past four years. In 1998, the average salary in education and related fields was half of that in public administration and industry, and a third of that in banking. Public-sector employees include doctors, teachers, social workers, and others who by tradition place great value on advanced education. Recently they have found it increasingly difficult to afford higher education for their children.

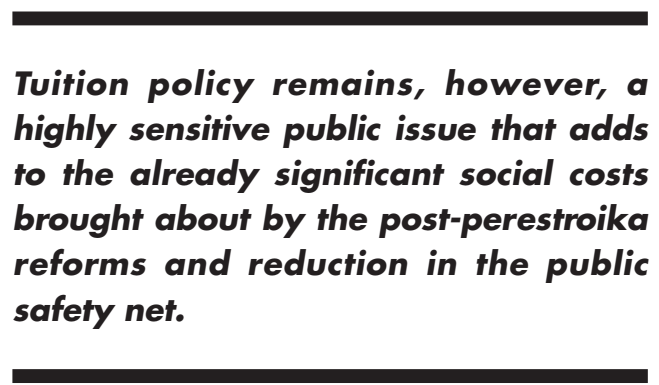

The competition for tuition-free admission at state higher education institutions remains high (with variations by discipline) and is likely to increase in the short term, due to the growing prestige of higher education among young people, the continuing growth of the university age cohort, a desire on the part of the young to delay military service, and youth unemployment.

This situation plays into the hands of more affluent people, who can afford tutoring for the more competitive entrance exams or are able to offer grossly underpaid university staff informal compensation in exchange for no-tuition admissions. According to some estimates, 60 percent of students in 1995 came from more affluent families, a group representing only 23 percent of the total population. This trend is likely to persist especially with the growth in the size of the student age cohort and the intense com- 
petition for no-tuition admissions. Students who are not being sponsored by a company often find themselves unable to continue their studies beyond the first year-due to lack of funds.

Many domestic experts on higher education rank tuition fees, complemented by means-tested financial aid and student loans, among the most effective ways to stabilize and expand higher education in Russia. Yet in a context of state austerity, compounded by strenuous economic challenges, such a solution can only be a long-term proposition.

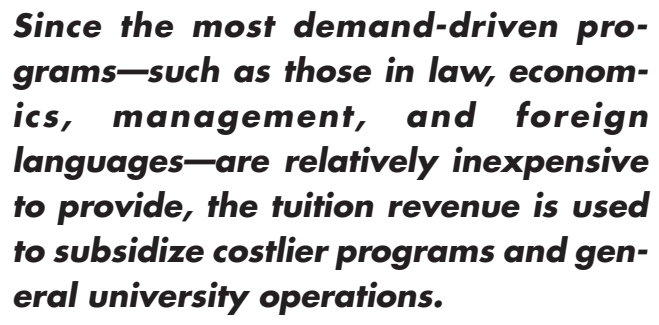

A proposal for introducing means-tested financial assistance came at the end of 1997 when the overall education reforms were being contemplated. However, the important issue of mechanisms for means-testing was not discussed. In any event, the proposal got stalled as being too radical to accept in its major components. In the short run, the major thrust of the reforms was to use available resources more effectively and to stimulate investments in education. The proposals recommended tax deductions on investments in higher education for both enterprises and individuals, needs-based student financial aid to target poor and out-of-town students-the amount of financial aid to be at least at the minimal subsistence level-and a for-fee expansion of auxiliary campus services with assistance for needy students.

These measures were aimed at stimulating resource flows to higher education from nonstate sources- that is, from businesses and individuals. The goal was to redirect resources from the "shadow" sector into a legal sector of education, to mitigate the growing inequality in access to higher education, and to decrease undifferentiated state subsidies for auxiliary campus services. There were counterarguments to these recommendations, and in early 1998 the proposed reform plan was not supported by Parliament. However, responding to the continuing pressure of state financial cuts, policymakers offered to lift the cap on tuition-based enrollments in public institutions, decrease the student-faculty ratio, redirect state financial aid solely to the needy, and reduce state-supported admissions. The last proposal triggered a number of student protests against the privatization of higher education. According to a student survey in the Urals, almost two-thirds of respondents expressed concern about their inability to complete their studies on a fee-paying basis, and only one-quarter indicated that they would be able to carry the full costs of higher education.

A rise in the number of state-supported admissions to public higher education has been reported as of fall 1999 . Yet the problems have continued to mount in higher education since the August 1998 financial setback. Recently, national policymakers have called on university leaders and other professionals to make a concerted brainstorming effort to come up with possible solutions. With the parties admitting the need for change, the effort is expected to reinvigorate higher education.

\section{The University of Malta's Student Stipend System}

\section{Ronald G. Sultana}

Ronald G. Sultana directs the Comparative Education Program in EuroMediterranean Studies, and is the head of the Department of Foundations in Education at the University of Malta. He was dean of the Faculty of Education (1997-1999) and is the founding editor of the Mediterranean Journal of Educational Studies. Address: Faculty of Education, University of Malta, Msida MSD 06, Malta. E-mail: <rsul1@educ.um.edu.mt>; web page: <http://www.educ.um.edu.mt/mep/mep.htm>.

t a time when the major trend in universities internaAtionally is for students to share at least some of the costs of their higher education, Malta remains what may well be a unique case: the government provides not only free instruc-

tion but also a stipend to all undergraduates. The stipend system originated in a series of reforms at the University of Malta ushered in by a Labour government in the 1970s. The reforms included, among other things, the introduction of a "student-worker scheme," whereby all students were obliged to find an employer-sponsor before being allowed access to a university degree program. Students were required to spend five months studying and five months working. In this way, the then government hoped to attract students from different socioeconomic backgrounds into postcompulsory education, ensure that graduates found employment, and encourage a shift away from the university's traditional focus on the old professions into new, more vocationally relevant areas. Students received a wage-pegged in the first year of sponsorship to half the salary of a clerk in the civil service, in the second year to that of an administrative assistant, and in 